\title{
Analysis of the Impact of Digitalization on the Development of Foreign Economic Activity During COVID-19 Pandemic
}

\author{
Shkalenko A.V. ${ }^{1, *}$ Fadeeva E.A. ${ }^{2}$ \\ ${ }^{1}$ Volgograd State University, pr-t Universitetsky, 100, Volgograd, 400062, Russia \\ ${ }^{2}$ Volgograd State Technical University, Lenin avenue, 28, Volgograd, 400005, Russia \\ *Corresponding author.Email: lavra.ne@mail.ru, oponir@volsu.ru
}

\begin{abstract}
The article describes the impact of the COVID-19 pandemic on the digitalization and foreign economic activity of states. The authors analysed a macroeconomic situation and highlighted its impact on the export climate of countries. They describe the institutional transformations caused by the opportunities and limitations of regulating the digital economy of foreign trade in the context of international economic integration. The article highlights the features of the oil market significantly affecting the formation of the economic policy of the state and the competitiveness of the state in the international market. It describes the role of economic statistics in managing the global economy. Researchers identified trends in institutional changes in the Russian economy under the influence of digitalization during the COVID-19 pandemic. They defined the role of international expansion in the process of digitalization of the economy, markets and global industries. The paper describes the trends in the institutional environment in digital business and international globalization. It identifies the main areas of influence of digitalization on the development of foreign economic activity.
\end{abstract}

Keywords: digital business, foreign trade relations, digitalization, pandemic, international business, institutions, export climate

\section{INTRODUCTION}

This research considers the impact of virology, namely the spread of the COVID-19 coronavirus infection on digital transformations in the social and economic activities of states resulting in changes in the development of the foreign economic activity. At the moment, it is difficult to measure this impact using such familiar indicators as employment, inflation and GDP, as they are often late. There are different scenarios and forecasts for the scaling up the viral pandemic and its impact on the digital economy. Exact numbers will appear soon. But today we are already witnessing dramatic changes in the institutional structure of all countries and the impact on foreign trade and economic relations.

Macroeconomic forecasts use not only a single indicator, namely, gross domestic product (GDP). In practice, it is customary to forecast each individual component, for example, the export of total production. Forecasts of disaggregated GDP are more accurate than direct forecasts, especially in the short term. Thus, more accurate forecasts for each component lead, other things being equal, to a reduction in GDP forecast errors. Lehmann, R. conducted an analysis that identified four survey-based indicators that he considered most effective in eighteen European countries: export climate, production expectations of domestic manufacturing companies, industrial confidence indicators and an indicator of economic sentiment [1].

\section{METHODOLOGY}

Macroeconomic analysis faced the problem of summing up identified behaviour (whether on an individual or market level) to an aggregate level where the corresponding behaviour differs between people and markets. There are two simple examples here. The first concerns consumption relations, which postulate that, for an individual, a higher disposable income will lead to higher consumer spending, but where increasing and average propensities for consumption differ from person to person. The question then arises: does the total consumption expenditure relate to the total disposable income of the household? And under what conditions is it occur? What is the nature of these relationships? The second may be wage changes, unemployment which may persist at the sectoral level. And again the question arises about what will be the corresponding aggregate relationship between wage change and unemployment?

The basis of this study is the use of elements of an innovative methodology of post-institutional analysis 
based on the interdisciplinary synthesis, which involves overcoming the monodimensionality, dichotomization and dogmatism of many concepts of orthodox neoinstitutionalism.

The desire to analyse the interaction of individual countries in the monetary economy is a difficult task. Unorthodox macroeconomic analysis has always faced many challenges in trying to understand the evolution of the economy and the impact of structural changes, policies, etc. on variables such as employment and unemployment, level of production, inflation, etc. Heterodox macroeconomists analyse the roles and interpretations of equilibrium analysis. Meanwhile, unorthodox macroeconomists often engage in cyclical analysis. At the moment, we see a huge impact of the COVID-19 virus on vital functions within the country and the development of foreign trade activity. Heterodox macroeconomic analysis usually recognizes that different sectors of the economy work differently, there may be differences between different sectors, their pricing and investment behaviour; between different types of firms; between social classes and genders in their consumption and saving behaviour, various types of labour markets, institutions and wage determination, etc. The heterodox macroeconomic analysis does not exclude the appeal to the representative agent from the main macroeconomic analysis. But in this situation, we are witnessing a tremendous impact that the COVID-19 virus has on the complete reformatting of the economic systems of all countries. There are structural shifts in baskets of ordinary consumers, distortion of goods exported and imported in different countries, the massive introduction of digital technologies, contactless delivery and payment for goods, changes in political agreements and institutional changes that lead to drastic transformations in society.

The viral revolution has triggered dramatic changes that are taking place in all spheres of human activity in all countries and peoples. We can already say that even after the end of the pandemic, the world will not be the same. The main areas of change will be employment, trade and health. The world economy has experienced several global economic crises in recent decades, but none of them has had such a profound impact on the introduction of digital technologies into all spheres of human activity and has not had such a drastic and dramatic impact on foreign trade relations between countries.

According to standard macroeconomic theory, foreign demand and the exchange rate or measure of competitiveness determine a country's exports. Three possible approaches can provide potential predicates for domestic exports. First, it is possible to use information or indicators that advance the development of exports directly from the domestic point of view. Second, each component of domestic exports is modelled separately, so it is necessary to select suitable indicators for either external demand or competitiveness And thirdly, we can apply an indicator that reflects both components together.

The export climate for each country depends on the global climate, approximating external demand, and an indicator that measures its relative price and cost competitiveness.
In turn, the global climate is dependent on exports, focused on the average economic climate and major trading partners for the domestic economy. The economic climate of each trading partner consists of consumer and business confidence.

At one level, money has a universal property, namely, a credit relationship is measured in units of the account that also measures prices, debts, etc. There is universality in the nature of money, in the sense that money is an asset, which is a common payment method expressed in a unit of account. Regardless of what form money takes and whether it is based on a commodity (for example, precious metal), it is a credit relationship.

Seccareccia and Correa argue that all unorthodox theories of money have a common starting point for the analysis of credit and debt relations in which production is a central element [3]. The Keynesian-Marxist structure describing the process of money circulation (the theory of money circulation) perhaps best represents this comprehensive vision. This broad analytical framework of TMC is compatible with institutional theories of money, which also indicate the importance of credit and debt relations.

According to experts, the COVID-19 pandemic announced by WHO on March 11, 2020, has not yet reached its peak. At the time of the official announcement of the coronavirus pandemic, we had the following data: the number of infected people in the world was 113 thousand 702 people, of which 80 thousand 924 people were in China. The incidence of COVID-19 virus morbidity and mortality is increasing every day and this negatively affects the economic and economic activities of all countries of the world. According to official figures, the number of officially registered unemployed in the USA as of April 3, 2020, has already reached 7 million. Growth in 2 months is more than 20 times. At the same time, the USA population is about 300 million. The Great Depression is actually happening again in the country. Inflated to insane proportions over the past 40 years, the service sector, where many did not have a permanent job, has burst. The huge number of people who were involved in it were actually on the verge of survival and deep in loans. Meanwhile, with most of the real production moved to China, China is now feeling much better than the US. Now the bubble of the service sector has burst and will pull the banking system. The collapse of banks will tear the rest of the economy to pieces. But the United States has no margin of safety in the domestic market, unlike China. We are not observing the widespread practice of increasing the share of unemployment in Russia, but we see a vivid tendency that, in Russia, small and mediumsized businesses are in a very difficult condition despite measures of support that the government is trying to introduce. It is predicted that $70 \%$ of enterprises will go bankrupt. Starting from April 4, 2020, Russia has introduced a moratorium on initiating bankruptcy cases against certain debtors; it will be valid for six months. According to Government Regulation No. 428 of 04/03/2020, creditors will not be able to file for bankruptcy against the following debtors: 1) organizations and individual entrepreneurs that are most affected by the 
spread of coronavirus infection; 2) organizations that are included in the list of backbone and strategic enterprises and strategic joint-stock companies [4].

Also, at the moment, we see that the price of oil is an important factor influencing the exchange rates, foreign trade transactions, as well as the income of the Russian budget. If this trend continues for a long time, it will lead to a reduction in reserves, which will entail a decrease in social benefits, an increase in taxes and, in turn, will result in a default. According to experts, if COVID-19 pandemic will be protracted, it is estimated that it will not end quickly; Russian oil will have a negative price. The oil market has its characteristics, which significantly affect the formation of the economic policy of the state and the competitiveness of the state in the international market. Firstly, the oil market is exclusively wholesale. Wholesale transactions always have complex contracts. The parties agree on deliveries for a month, a quarter, and even a year in advance, and fix the price. Further, market prices do not have much influence on the parties because they have a contract in force and it is not economically feasible to withdraw from it. Because there are big penalties.

Secondly, wholesale sales have the three most important components: storage costs, transportation costs, discounts for large volumes. They ultimately affect the price of the goods actually shipped.

Thirdly, the oil market is very heterogeneous. Many are equal to the price of Brent oil, but in fact, they mostly trade in other varieties of oil in the world. There are more than a dozen of them. From some of them, they make fuel oil, from others they make petrol, polymers and so on. Sometimes different grades of oil have to be mixed to increase fluidity, otherwise, it will not flow through the pipeline.

Fourth, there is a huge difference in the cost of production and transportation for different oil producers. Many producers specializing in shale oil have a production cost of $\$ 60$, and the Saudis have wells costing $\$ 8$ per barrel. That is, at $\$ 30$ per barrel, some are guaranteed bankrupt, while others remain in profit. The cost of transportation to the final consumer is also important. Those who produce oil near the sea win before those who extract it deep in Siberia and have to drive it through a huge pipeline to the final consumer, for example, in China. Producers working through the pipeline are wholly dependent on the buyer to whom pipeline is laid, and producers transporting by tankers can choose the buyer. Secondly, transportation through the pipeline is several times more expensive. So, the cost of transportation also affects the cost of production, which is most often contracted out entirely on the shoulders of the oil miner. When the price of oil drops low enough, the cost of delivery can make a price for product negative for its supplier.

Fifth, the role of storage facilities in the oil market is also important. So that oil consumers do not have sharp downtime, the producer uses huge storage facilities of tens of thousands of tons. The decisions that they make strongly affect the price. If they make stocks with the expectation that the price will continue to rise, then they push the price up. If they dump stocks on the market, believing that the price will only fall, then thereby they bring down the price even more.

Sixth, the expenditures of developing new wells, access to investment and technology influence the cost. Everything here is heterogeneous, too. Someone is developing cheap wells right now, but all the next ones will be twice the expenditure. Someone can continue development with the same cost. And someone cannot develop at all because it is sanctioned, and he cannot buy the necessary equipment. This is exactly what happened to the Russian Federation after the annexation of Crimea. All of this resulted in reshaping of the world's oil and gas market. US sanctions have weakened Russia's position in this market.

Seventh, market share and sales are crucial. As in any production, super-profits are available at large volumes with the approximately fixed cost. If a country invests a lot of money in production and transportation and sells a little product, then it either has no profit or has a loss. Market share is the most important factor in the oil market.

Eighth, there are price wars. In fact, there are still huge oil reserves in the world. Moreover, demand for it will be high for at least the next 50 years. Therefore, there are many developing technologies to reduce production costs. Global warming is opening up new mining options in the permafrost zone. In general, the oil market is very competitive. If competitors have not divided sales on it and a price war begins for a certain consumer, then profits on it will quickly be blown away to zero or even become negative. For this, there are organizations such as OPEC, so that producer can earn and forecast their profits. Indeed, the inertia in this market is enormous: production preparation, construction of pipelines or ports/tankers, construction and operation of oil storage facilities.

Ninth, the growth in demand from industries is affecting factor. Countries with strong industry and domestic markets (transport fuel needs) are the first to buy oil. If in the world industry grows faster than producers manage to extract oil, then the price of black gold rushes up. If the industry stalls, there are no big needs in oil. Then its price drops smoothly. Because the number of producers remains, but the demand does not increase.

Tenth, the price of oil is the expectation of the future. Oil quotes on the stock exchange much more than other products depend on the expectations of the future. Will the industry grow actively? Will a military conflict begin somewhere? Will internal combustion engines be replaced by electric ones? This market is very sensitive to any news. And the oil prices reflect more likely how its participants see the market position in six months, and not right now. They lay these expectations in the price.

According to the forecasts of the Centre for Applied Macroeconomic Analysis and short-term forecasting, the situation with the coronavirus epidemic and oil prices is developing according to a shock scenario [5]. For the Russian economy, this means that lower oil prices causing a contraction in domestic demand will lead to the fact that a significant part of enterprises quitting the quarantine simply cannot fully re-open. And the longer the quarantine lasts, the harder this effect. 
In the presence of two factors: long quarantine and very low oil prices plus low global demand for Russian products, it will not be possible to turn the tide of the situation with only one financial policy. The Russian economy is still likely to expect, with high probability, a two-year recession corresponding in duration to the global economic downturn in this scenario.

But it is possible to significantly reduce the scale of this recession, and especially its social consequences. In this scenario, the decline of GDP will be contained at 2.3$2.5 \%$ in 2020 and $0.5-0.8 \%$ in 2021 , a gain of $0.6-1.0 \%$ will be in 2022 (see Figure 1). That is, the gain of GDP in the hard crisis scenario will be $0.5-0.8 \%$ in 2020 and 0.1 $0.3 \%$ in 2021 and 2022.

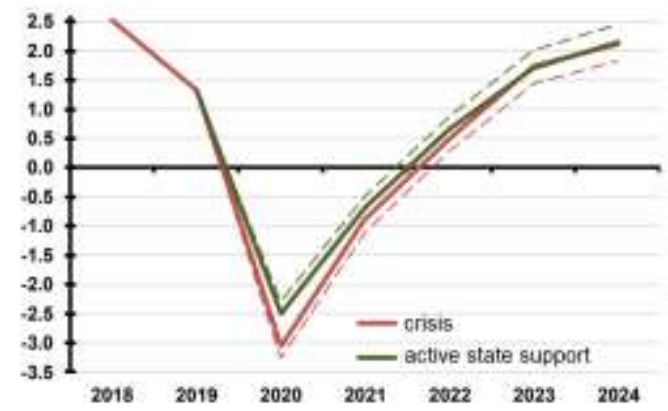

Figure 1 GDP dynamics, growth rate, $\%$

Accordingly, if in the crisis scenario it can reach 6.7-7.0\% of the workforce in 2021-2022, one and a half times higher than the level of 2019, then in the scenario with active state support of the economy in 2021, it can be kept at 5.5$5.8 \%$, with a further intensive decline.

Given moderate unemployment, the gain in the dynamics of real disposable incomes of the population is also quite large, $1.0-1.3 \%$ in $2020,0.4-0.7 \%$ in $2021,0.1-0.3 \%$ in 2021. Considering the small business crisis, if in the crisis scenario the drop in goods turnover could reach 2.5-3\% already in 2020 and $1.7-2 \%$ more in 2021 , then in this scenario this decline is almost one and a half times less deep, respectively, $1.5-2 \%$ in 2020 and $1-1.2 \%$ in 2021, followed by a transition to rather intensive growth (see Figure 2). The gain of investment dynamics in this scenario is small and is estimated at $0.3-0.7 \%$ in $2020,0.5$ $1.0 \%$ in 2021 , up to $0.3 \%$ in 2022.

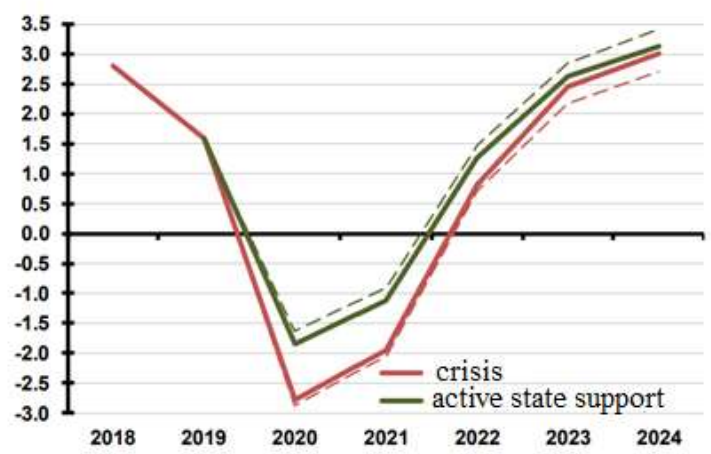

Figure 2 Dynamics of retail turnover, the growth rate in\%
In this situation, we see that digitalization has not only challenged the foundations of international business and forced it to reconsider its priorities, but it is the only true institutional transformation that will allow us to overcome the global crisis after the end of the COVID-19 pandemic. Studies have long emphasized how information technology is changing the process of internationalization, emphasizing such clear advantages as reducing transaction costs, saving user networks, speed and scalability [6; 7; eight]. However, there is a growing understanding that digitalization not only changes information costs in the cross-border transfer of firm-specific advantages (FSAs) but also changes the nature of FSA itself [9]. As early as 1970, Harvard sociologist Daniel Bell introduced the term post-industrial society describing the changes expected to result from new technology at the time.

Economic statistics play an indispensable role in managing the global economy. In world politics, realists see only a struggle for domination fuelled by mutual distrust and resolved by the relative strength that countries can bring and alliances that they manage to form. Avoiding such a world, countries have created a dense network of international organizations that put the global order on a more solid foundation. In the international economic administration, harmonized statistics allow governments to streamline their economic affairs, smooth out interactions, and support potential conflict. For example, the balance of payments statistics are critical to the work of the World Trade Organization (WTO) and the International Monetary Fund (IMF); per-capita welfare information is important to the World Bank. Public debt statistics underpin the European Union's Single European Currency arrangements. International investors base their valuations and investment decisions on country-level economic data. The core credibility of these data, in turn, confirms government support for an open international economic order. Both public and private actors must believe that statistics can be considered a neutral arbiter in world affairs. Based on this, they accept economic statistics as a tool for monitoring international economic agreements. These figures also provide countries with information on their bilateral economic relations, and they provide objective data through which international institutions, and therefore international investors and national governments themselves, perceive economic development.

\section{RESULTS}

The dominance of technological forces and the need to develop and disseminate innovations in several markets are characteristics of international industries in the modern world. Success in these industries depends on the ability to use technological forces, produce new products and duplicate the process in various national markets [10]. In general, new products are developed domestically. These products are then exported to overseas markets, and related technologies are subsequently applied to other national markets. Since competitive advantage depends on costly technological development, the possibility of duplication 
of technology in several markets is an economic necessity [11]. The need to apply new technologies in several national markets stimulates the emergence of international industries.

The ability of multinational corporations to benefit from economies of scale and experience, location, product differentiation, process technology and control of distribution channels explains their international expansion. Some of these benefits are only possible with a global integration strategy. Some technologies and products require huge investments in $\mathrm{R} \& \mathrm{D}$ and production facilities. In such situations, organizational effectiveness requires a large volume of production and market share on a global scale. Consequently, the imperative of efficiency creates global industries. Global industries have a highly centralized large manufacturing and research operations and standardized products. Chemical, consumer electronics (such as mobile phones and laptops), heavy equipment, commercial aircraft and shipbuilding industries are considered global.

Global operational requirements need in huge investment capital to create a global network of production and distribution. R\&D investment demands are also great. Economic imperatives have forced global industries to globalize their operations. There are no national markets with an annual absorption capacity of this size. This enormous increase in economic production has made globalization a necessity. Lower transport and communication costs, as well as relatively low import restrictions, have also made globalization possible in these industries.

In these industries, since product and market requirements are global, products are manufactured, sold and serviced around the world without any change. In other words, consumers' needs for goods are the same for different markets. For these products, national and local tastes do not differ, and there is no need to customize the products by national standards. Government intervention and regulation in global industries are relatively small. Consequently, firms can locate production facilities anywhere in the world, which provides the most economic benefits

\section{CONCLUSION}

Today, digital business is an integral part of the market worldwide, as it is significant to meet the wishes and requirements of customers. In this context, the introduction of digital business is particularly relevant to the economy since the availability of online services is an important factor in global competition. Digital business is one of the most important applications areas of new digital information and communication technologies. Networked Internet applications represent the sustainable simplification and individualization of communication and information brokerage services. In this society, the secondary sector of the economy is losing importance because of the economic system is mainly based on information technology, and not on production. As the main areas of influence of digitalization on the development of foreign economic activity, we can distinguish the following results.

First, the growing digitization of products and services, the rapid development of products and services, and the high innovativeness and innovative dynamics are key factors. Innovation is one of the key figures in the Internet economy and digital business. Dynamic changes in the business environment in the Internet economy lead to innovations that are happening shorter and intermittently. Therefore, companies must have significant adaptability in the market.

Secondly, the main driving factors of the market are increasing its transparency, increasing market fragmentation, reduced market entry and switching barriers (especially in the electronic services sector) and disintermediation.

Third, customers empowerment also matters. This change in the business environment mainly concerns the customers themselves. Modern information and communication technologies have made possible the growing transparency of accountability of actions, as well as the possibility that customers can share their desires and opinions and unite in social networks and communities. Customers not only require greater involvement in manufacturing and design but also updated B2C collaboration. Here, companies must operate, for example, by providing a more transparent form of production, management and development through the integration of customers.

\section{ACKNOWLEDGMENT}

The reported study was funded by RFBR according to the research project № 18-2916132.

\section{REFERENCES}

[1] R. Lehmann, A. Weyh, (2016) Forecasting employment in Europe: are survey results helpful? J Bus Cycle Res 2016, 12(1), pp.81-117

[2] I. Steedman, Questions for Kaleckians. Rev Polit Econ, 1992, 4(2), pp. 125-151. DOI: https://doi.org/10.1080/09538259200000011

[3] M. Seccareccia, E. Correa (2018) Rethinking money as an institution of capitalism and the theory of monetary circulation: what can modern heterodox economsits/institutionalists learn from Karl Polanyi? J Econ Issues, 2018, 52(2), pp. 422-429. DOI: https://doi.org/10.1080/00213524.2018.1469889

[4] Decree of the Government of the Russian Federation No. 42 of 04/03/2020 "On the introduction of a moratorium on bankruptcy proceedings upon the application of creditors in respect of individual debtors" 
URL:

http://static.government.ru/media/files/q3x1rrVAA325 WgKQq3cJu9kAXM1W6Imn.pdf.

[5] D.R. Belousov, O.G. Solntsev et al. On the contours of the constructive version of the forecast, 2020. URL: http://www.forecast.ru/Forecast/kfore042020.pdf

[6] K. Brouthers, K. Geisser, F. Rothlauf, Explaining the internationalization of ibusiness firms. Journal of International Business Studies, 2016. 47(5) pp. 513534. DOI: https://doi.org/10.1057/jibs.2015.20

[7] S. Kotha, V. Rindova, F. Rothaermel, F. Assets and Actions: Firm-Specific Factors in the Internationalization of U.S. Internet Firms. J Int Bus Stud, 2001, 32, pp. 769-791. DOI: https://doi.org/10.1057/palgrave.jibs.8490994.

[8] N. Singh, S. Kundu, Explaining the Growth of ECommerce Corporations (ECCs): An Extension and Application of the Eclectic Paradigm. J Int Bus Stud, 2002, 33, pp. 679-697. DOI: https://doi.org/10.1057/palgrave.jibs.8491039

[9] R. Strange, A. Zucchella, A. 2017. Industry 4.0, global value chains and international business. Multinational Business Review, 2017. 25(3), pp. 174184. DOI: https://doi.org/10.1108/MBR-05-2017-0028.

[10] A.O. Inshakova, E.I. Inshakova, A.V. Lavrentyeva Determinants and Prospects for the Legal Harmonization of the Intra-BRICS Trade Turnover in the Digital Form. 2020. DOI: 10.1007/978-3-03029586-8_25.

[11] D.P. Frolov, A.V. Lavrentyeva Digital/Smart Places and Their Strategies: Conceptualizing the Recent Trends. Lect Notes Networks Syst, 2020; 87 pp. 435441. DOI: 10.1007/978-3-030-29586-8_50. 